\title{
Criminal Responsibility on Captain of Commersial Vessel by Act No 17 of 2008 on Voyage
}

\author{
Subekhan ${ }^{1}$ and Lathifah Hanim ${ }^{2}$
}

Abstract. The cruise is one of the nation's transportation system that has a strategic importance and as a liaison and outreach throughout the territory of Indonesia's sovereignty and the potential beneficial role for society, both nationally and internationally. The problems of this study are: 1 ) Why the skipper commercial vessels should be responsible in case of Vesselwreck, 2) How does the skipper criminal liability due to accidents aboard commercial vessels according to Act No. 17 of 2008 On Voyage? 3) Is it possible corporate criminal liability in accidents merchant vessel according to Act No. 17 Of 2008 On Voyage?

Researchers used the method is legal normative juridical approach and specification in this study were included descriptive analysis. Sources and types of data in this research is secondary data obtained from the study of literature. Data were analyzed qualitatively. The problems studied by the theory of legal certainty and criminal liability.

Based on the results of research that skipper as a leader on the Vessel, is fully responsible for the safety of the Vessel, passengers and cargo during the voyage from the port of loading to the port of destination. Criminal sanctions needed to enforce these responsibilities, and sanctions that have been regulated in Act No. 17 Of 2008 on Voyage Article 244 paragraph (3) and (4), 20 Article 247 and Article 248 shall be punished with imprisonment beyond three (3) years or a fine of Rp 400.000.000.00, - (four hundred million). Obliged to take countermeasures, ask or give aid and spread the news of the Vesselwreck to others. If an accident occurs on board the skipper must be above board and record events such accidents in the logbook and reported to the harbor master. There are still many weaknesses of criminal responsibility in the corporation, among others: when the corporation is declared as a criminal, how the corporation is responsible, the types of sanctions what can be meted out to the corporation, not regulated penal substitute fines are not paid by the corporation and unregulated the offense to corporation. Because implementation guidelines in the draft penal Code there is renewal in the subject field of the offense and criminal liability system.

Keywords: Commercial Vessels; Skipper; Criminal Liability.

\section{Introduction}

The cruise is one of the nation's transportation system that has a strategic importance and as a liaison and outreach throughout the territory of Indonesia's sovereignty and the potential beneficial role for society, both nationally and internationally. Act No. 17 of 2008 on Voyage expected to be able to control and supervise all kinds of activities in the waters of Indonesia. Voyage activities in general is to transport freight or passengers from one location to another or from one port to another port, safety of

\footnotetext{
${ }^{1}$ Student of Master of Law, Universitas Islam Sultan Agung Semarang and Seaferer/Sailorman, email: subekhan_khan@yahoo.co.id

${ }^{2}$ Lecturer of Master of Law, Sultan Agung Islamic University (UNISSULA), Semarang
} 
navigation and protection of the maritime environment from pollution pollutants from Vessels. $^{3}$

The efforts made by the government in the field of marine transportation, among others to rehabilitate and increase the capacity of existing infrastructure, such as the procurement of human transport Vessels and Vessels carrying goods, improvement of seaports in Indonesia, container terminals and jetties. It aims to further facilitate interisland sea traffic, boosting trade within the country or International country. So important marine transportation Indonesian President Joko Widodo introduce sea Toll Progam he found marine highway infrastructure is important, he demonstrated, the price of cement in Java Rp 50-60 thousand. But in Papua to Rp 1 million even Rp.1.2 million or Rp.1,5 million. If the sea motorway was built, in Sumatra, Java, Kalimantan, Sulawesi, Papua, will give a sense of justice. ${ }^{4}$ In the Indonesian island states, especially in sea transportation is one way to channel the needs of the main requirements to the needs of complementary or auxiliary. It is undeniable that the marine transportation infrastructure in the archipelago like Indonesia has been a major supporter of the movement distribution items in bulk by Vessel. In terms of economics and business use of means of transport by Vessel is more effective and beneficial, so that with the infrastructure of marine transportation such as Vessels useful for the transfer of goods and people from one place to another, is expected to be followed by economic activity society good and positive impact in improving the economy in areas of Indonesia. ${ }^{5}$

Against accidents merchant vessel, the relevant parties should be responsible for both the Harbor Master, the master or the Voyage company:

- Harbor Master. Voyage safety is inseparable from the role of Harbor Master for the biggest problem begins Voyage accidents on the waiver procedure or in other words Harbor Master not carry out the task properly.

- Vessel skipper was one of the crew of the supreme leader in Vessel and have the authority and responsibility in accordance with certain provisions of the legislation. The skipper is obliged to act with skill, thoroughness and wisdom enough to do their job properly. The skipper is basically the person most responsible for everything that happens on the Vessel. He demanded to know and understand all of the characteristics of each unit on the Vessel concerned, whether directly related to the operation of Vessels or which merely assist the cruise. Besides, the skipper must understand correctly the number of passengers as well as cargo Vessels and other goods as the completeness of the Vessel.

- Voyage Company. Skills entire crew in taking a cruise, the risk of accidents on the high seas vessels remain there, so it takes a good and tight supervision on a Vessel in the voyage.

\footnotetext{
${ }^{3}$ Pujiati, 2016, "Pertanggungjawaban Pidana Korporasi Dalam Tindak Pidana Pelayaran (Criminal Liability Of Corporate Crime Of Shipping), IUS Journal, Vol IV, No. 1, April, Study of Law and Justice, p. 2.

4 Dani Prabowo Jokowi fokus bangun tol laut untuk pemerataan, https://nasional.kompas.com/read/2014/06/15/2140590/Jokowi.Fokus.Bangun.Tol.Laut.untuk.Pemerat $\frac{\text { aan }}{5}$

${ }^{5}$ Vicky Hanggara Alexandro, 2017, "Pertanggungjawaban Pidana Terhadap Kecelakaan Kapal Akibat Tidak Laik Laut”, Jurnal Hukum Adigama, Fakultas Hukum Universitas Tarumanagara, p. 4.
} 
Here are some types of Vessel wrecks from the period 2015-2019 there was an increase / decrease

\begin{tabular}{ccccccc}
\hline $\begin{array}{c}\text { Classification by type of } \\
\text { accident investigation }\end{array}$ & $2015-2019$ & 2019 & 2018 & 2017 & 2016 & 2015 \\
\hline aground & 16 & 1 & 4 & 6 & 3 & 2 \\
\hline Fire & 55 & 5 & 10 & 14 & 4 & 4 \\
\hline Etc & 16 & 4 & 8 & 2 & 2 & 0 \\
\hline sink & 48 & 5 & 14 & 6 & 6 & 3 \\
\hline Collision & 31 & 5 & 3 & 6 & 3 & 2 \\
\hline
\end{tabular}

Based on the background of the problems that have been described, it can be used to discuss a problem as follows: Why skipper commercial vessels should be responsible in case of Vesselwreck?; How does the skipper criminal liability due to accidents aboard commercial vessels according to Act No. 17 Of 2008 On Voyage?; and Is it possible corporate criminal liability in accidents merchant vessel according to Act No. 17 Of 2008 On Voyage?

\section{Research methods}

Researchers used the method is legal normative juridical approach and specification in this study were included descriptive analysis. As for sources and types of data in this research is secondary data obtained from the study of literature. Data were analyzed qualitatively. The problems studied by the theory of legal certainty and criminal liability.

\section{Results and Discussion}

\subsection{Vessel Skippers Commerce Must Accept Responsibility If The Accident Occurred Vessels}

In labor relations in the field of maritime transport, we recognize the existence of three groups of people, namely entrepreneur Vessel or the Voyage company, the captain and the crew, either as a Vessel's officer or classification. Each person involved in working in the Vessel should work just as well for the purpose of the voyage was met. Third parties involved are generally bound by a particular treaty, and must have specific permission to be able to work together in a Voyage business. This of course meant that each of each party can work with full responsibility, in accordance with what has been stated in the permit or the agreement. So if there is a problem in Voyage caused by human error, it will immediately be known and anticipated, In the case of Vesselwreck, there are three forms of accountability when the skipper was convicted, namely: ${ }^{6}$

- Administrative accountability

\footnotetext{
${ }^{6}$ The interview with Bambang Irawan, ST., M.Mar.E, as Members of the accident investigation Ships in NTSC, on March 16, 2020, 13:15 pm
} 
Administrative accountability is accountability that comes after the ruling of the Court Voyage which states that a skipper is guilty or not. Forms of administrative accountability is by warning or temporary revocation of a Certificate of Expertise Sailors owned by the skipper with a maximum period of two years (Article 253 paragraph (2) of the Voyage Law).

- Civil Liability

In the Vessel accident, in particular the collision of Vessels, civil liability is charged to the carrier company where working skipper. It is regulated in Article 1367 of the Civil Code which states that a person is not only responsible for the losses incurred by it but also be responsible for damages issued by dependents.

- Criminal Liability

Criminal liability arising from the new skipper of skipper when the action turned out to meet the elements contained in the provisions of the Code of Penal (Penal Code). But before the skipper should be found guilty of first administratively.

Work on a Vessel are highly demanded a discipline arising from the consciousness itself. As an example of a crew who do not wear personal protective equipment, reason is deliberately not using safety equipment as a nuisance and create movement on the job is not free, because he thought it was unnecessary. This is proof that obedience / discipline of the crew members is lacking. If the attitude of the crew may endanger himself and fellow-workers, the need for measures for the enforcement of discipline. Measures enforcement of discipline to do with the psychological approach among officers and subordinates that is with supervision and counseling intimate and family at the time of the crew members will carry out their duties. Besides this discipline enforcement actions can also be carried out with a warning system even to the termination / dismissal if the case is really dangerous, and the crew had repeatedly violated the warning. However, both owners and the entire crew are responsible for the safety, should be equally good enforce work discipline. Whereby the employer vessels should be disciplined in the procurement of equipment safety and otherwise support crew must comply with the provisions outlined in the safety on board. should be equally good enforce work discipline. Whereby the employer vessels should be disciplined in the procurement of equipment safety and otherwise support crew must comply with the provisions outlined in the safety on board. should be equally good enforce work discipline. Whereby the employer vessels should be disciplined in the procurement of equipment safety and otherwise support crew must comply with the provisions outlined in the safety on board. ${ }^{7}$

So the causes merchant Vessel's captain should be responsible in case of Vesselwreck for the skipper as a leader on the Vessel, is fully responsible for the safety of the Vessel, passengers and cargo during the voyage from the port of loading to the port of destination. Criminal sanctions needed to enforce these responsibilities, and sanctions that have been regulated in Act No. 17 Of 2008 On Voyage.

\footnotetext{
${ }^{7}$ Tjahjant, R. 2017. Analisis Penyebab Terjadinya Kecelakaan Kerja di Atas Kapal MV CS BRAVE. Journal ship. Vol. 11. February 2017 (p. 16)
} 


\subsection{Vessel Skipper Criminal Liability Accident Commercial Vessel According to Act No. 17 of 2008 on Voyage}

In Voyage, the potential for disaster or calamity that befell a very large Vessel that can lead to an accident on the Vessel. This situation can occur because of human error or natural events like a Vesselwreck, the Vessel ran aground, collision of Vessels, and others. ${ }^{8}$ If the accident resulted in passenger and goods needed help and rescue, then the next will cause any harm to the parties.

The first group of the marine loss is about the collision of Vessels, which in KUHD regulated in Article 534 to 544a. According to Article 3, S.1933-49, provisions concerning the Vessel collision applies to indigenous Indonesian people. Understanding of the Vessel collision stated in Article 534 paragraph (2) which reads: "The Vessel is called the collision or collision between vessels touching each other." Accidents on Vessels of course many causes loss of property and life. When viewed from the cause, then the accidents were mostly caused by: ${ }^{9}$ Factors carrier ; Factors passengers; Factors such conveyance tool ; Factors terrain where ; Factors weak oversight

In a Vessel accident of course also be closely connected with Voyage safety elements starting from Vessel safety is a factor internal to external factors. ${ }^{10}$ These factors, among others: Safety factors; Suitable standart factors; Sailing safety factors; Factor Voyage safety.

In addition, vessel accidents often occur due to lack of knowledge possessed by the Vessel owner and the Vessel's master. This is particularly true for people sailing, fishing or people who use the Vessel as a means of transportation other short distance. Generally they do not have sufficient knowledge to run a cruise-Vessel in the busy Voyage. In such circumstances, accidents are sometimes unavoidable Vessel because one party has been running the Vessel according to the procedure but on the part of the other, because of lack of knowledge, running the Vessel at will as they want without regard to the existing rules. ${ }^{11}$

The skipper should not leave the Vessel during the voyage or when there is imminent danger, except when absolutely necessary absence or forced to it by the rescue effort themselves. Upon arrival at a port, the skipper can make your employees who are authorized to make a statement about the incident on the way the Vessel. If need be, for the safety of the Vessel or its cargo, the captain has the authority to throw into the sea or wear-out equipment and part of the cargo Vessel. The skipper in case of emergency during the trip is authorized to take by paying compensation, food

\footnotetext{
${ }^{8}$ Hukum Maritim, Kecelakaan Kapal, by Chandra Motik Yusuf, SH, M.Sc., Ph.D., delivered on Maritime Law Lecture Semester 2008/2009

${ }^{9}$ Sylvia Frances Tan, 1988, Pertanggungan Penumpang pada Kecelakaan Kapal di Perairan Pedalaman Kalimantan Barat, Indonesia University, Depok, p. 47-49.

${ }^{10}$ Capt. Willis Tjahjo Gerilyanto 2010, Slide Etika Persidangan dan Metode Penulisan Putusan Mahkamah Pelayaran, Mahkamah Pelayaran, Jakarta, p. 5.

${ }^{11}$ The interview with Bambang Irawan, ST., M.Mar.E, as Members of the accident investigation in the NTSC ship, on March 16, 2020, 13:15 pm
} 
ingredients available on the passengers or including cargo, to be used for the sake of everyone on board. The skipper has disciplinary authority over the crew. ${ }^{12}$ Vessel skipper Criminal Liability Accident Commercial Vessel According to Act No. 17 Of 2008 On Voyage is obliged to take countermeasures, ask or give aid and spread the news of the Vesselwreck to others. If an accident occurs on board the skipper must be above board and record events such accidents in the logbook and reported to the harbor master.

\subsection{In the Corporate Criminal Liability In Commerce Vessel Accident According to Act No. 17 of 2008 on Voyage}

Voyage activities in general is to transport freight or passengers from one location to another or from one port to another port, safety of navigation and protection of the maritime environment from pollution pollutants from Vessels. In the science of criminal law "theory of retaliation" and "theory of interest" in terms of punishment of the perpetrators, too long began to be abandoned, with their combined theory (Theorie vereenigings) as opinions expressed by Jeremi Bertham which says that: "Criminal should not be groundless (without base), the Needless (unprofitable), and unprofitable (not useful) or inefficacious, but must use approaches that can provide utility (in terms of expediency) with regard to the great happiness of the great number (happiness the largest for many people) ". ${ }^{13}$

The provisions of punishment as contained in Act No. 17 Of 2008 On Voyage could not be separated from the theory about the purpose of sentencing and criminal wisdom in general. In the doctrine of science in criminal law doctrine known science three theories about sentencing, namely:

- Retaliation theory, which considers that the basis of criminal law is thought to retaliation;

- Theory goal / prevention, which assumes that the criminal law basis is situated on the criminal purpose itself principally to maintain public order;

- The combined theory, which assumes that the criminal should be based on the purpose of retaliation applied in combinations that emphasize one of the elements eliminating other elements, as well as on all elements.

Corporate criminal liability in accidents in commercial vessels according to Act No. 17 Of 2008 On Voyage are still many weaknesses, as in the draft Penal Code there is renewal in the subject field of the offense and criminal liability system. In the subject field of the offense, recognizing corporations as perpetrators and accountable in criminal law (corporate criminal liability). While in the field of criminal accountability system. The draft Penal Code still adheres to the principle of error as a principle fundamental to account for the offender. But in certain things to remember and keep track of progress in the field of technology and information, the draft Penal Code recognizes the principle deviation error, namely the principle of strict liability and vicarious admit liability.

\footnotetext{
12 Djaja, D. Adi Indra Bambang Setiono Kusna, 2008, Hukum Laut dan Perkapalan, Direktorat Pembinaan Sekolah Menengah Kejuruan, Jakarta, Bab.XIII.

${ }^{13}$ Roni Wiyanto, 2012, Asas - Asas Hukum Pidana Indonesia, print I, Mandar Maju, Bandung, p. 117-118
} 


\section{Closing}

\subsection{Conclusion}

- The skipper commercial vessels should be responsible in case of Vesselwreck for the skipper as a leader on the Vessel, is fully responsible for the safety of the Vessel, passengers and cargo during the voyage from the port of loading to the port of destination. Criminal sanctions needed to enforce these responsibilities, and sanctions that have been regulated in Act No. 17 Of 2008 On Voyage, especially in chapter 330, which reads; The skipper who knows the dangers and accidents on the Vessel, another Vessel, or any person who is found in a state of danger, which do not take preventive measures and disseminate news about those rights to another party, 244 paragraph (3) and (4), Article 247 and Article 248 shall be punished with imprisonment of three (3) years or a fine of $\mathrm{Rp} \mathrm{400.000.000.00,} \mathrm{-} \mathrm{(four} \mathrm{hundred}$ million).

- Vessel skipper Criminal Liability Accident Commercial Vessel According to Act No. 17 Of 2008 On Voyage is obliged to take countermeasures, ask or give aid and spread the news of the Vesselwreck to others. If an accident occurs on board the skipper must be above board and record events such accidents in the logbook and reported to the harbor master.

- Criminal responsibility as a corporation in the accident merchant vessel according to Act No. 17 Of 2008 On Voyage are still many weaknesses, among others: when the corporation is declared as a criminal, how the corporation is responsible, the kinds of sanction anything that can be imposed on corporations, unregulated substitutes criminal fines are not paid by the corporation and does not set on the guidelines for application of the criminal against corporation. Because in the draft penal Code are the subject of renewal in the field of criminal offense and accountability systems.

\subsection{Suggestion}

- for the Government

The government should immediately increase the fleet and complementary facilities and infrastructure of more sophisticated considering the territory of Indonesia is largely the archipelago, the frequent occurrence of accidents at sea and the river.

- for the Community

In order for the law on the cruise to be better, especially on the criminal in an accident to take a staggering toll.

- for skipper

The skipper as supreme leader on board to be able to carry out the duties and responsibilities by increasing the sense of high discipline to all the crew in doing exercises or guidance of the use of safety equipment are on board, so the crew really understand on how to use the safety equipment on board as well as other equipment. With the increased knowledge and skills as well as supervision of the crew, it is expected to carry out everyday tasks on board, Vessel accidents can be prevented or reduced as low as possible. 


\section{References}

[1] Dani Prabowo Jokowi fokus bangun tol laut untuk pemerataan, https://nasional.kompas.com/read/2014/06/15/2140590/Jokowi.Fokus.Bangun.T ol.Laut.untuk.Pemerataan

[2] Djaja, D. Adi Indra Bambang Setiono Kusna, 2008, Hukum Laut dan Perkapalan, Direktorat Pembinaan Sekolah Menengah Kejuruan, Jakarta.

[3] Hukum Maritim, Kecelakaan Kapal, by Chandra Motik Yusuf, SH, M.Sc., Ph.D., delivered on Maritime Law Lecture Semester 2008/2009

[4] Pujiati, 2016, "Pertanggungjawaban Pidana Korporasi Dalam Tindak Pidana Pelayaran (Criminal Liability Of Corporate Crime Of Voyage), Jurnal IUS, Vol IV, Nomor 1, April, Kajian Hukum dan Keadilan.

[5] Roni Wiyanto, 2012, Asas - Asas Hukum Pidana Indonesia, print I, Mandar Maju, Bandung.

[6] Sylvia Frances Tan, 1988, Pertanggungan Penumpang pada Kecelakaan Kapal di Perairan Pedalaman Kalimantan Barat, Universitas Indonesia, Depok.

[7] Tjahjant, R. 2017. Analisis Penyebab Terjadinya Kecelakaan Kerja di Atas Kapal MV CS BRAVE. Jurnal kapal. Vol. 11. February 2017.

[8] Vicky Hanggara Alexandro, 2017, "Pertanggungjawaban Pidana Terhadap Kecelakaan Kapal Akibat Tidak Laik Laut", Jurnal Hukum Adigama, Fakultas Hukum Universitas Tarumanagara. 